DEPARTMENT OF THE INTERIOR

U.S. GEOLOGICAL SURVEY

\title{
MEASURED STRATIGRAPHIC SECTIONS OF THE \\ LOWER PERMIAN NILAWAHAN GROUP, SALT RANGE, PUNJAB PROVINCE, PARISTAN
}

B.E. Law ${ }^{1}$ and T. Hussnain ${ }^{2}$

\section{U.S. Geological Survey Open-File Report 89-464}

Report prepared jointly by the Geological Survey of Pakistan and the U.S. Geological Survey under the auspices of the U.S. Agency for International Development.

This report is preliminary and has not been reviewed for conformity with U.S. Geological Survey editorial standards and stratigraphic nomenclature.

${ }^{1}$ U.S. Geological Survey, Box 25046, Denver Federal Center, Denver, Colorado 80225

2 Ministry of Petroleum and Natural Resources, Geological Survey of Pakistan, Lahore, Pakistan 54660 


\section{CONTENTS}

Page

Introduction.$\ldots \ldots \ldots \ldots \ldots \ldots \ldots \ldots \ldots \ldots \ldots \ldots \ldots \ldots \ldots \ldots \ldots$

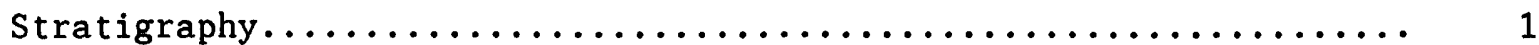

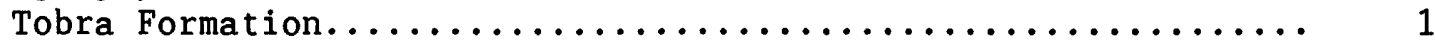

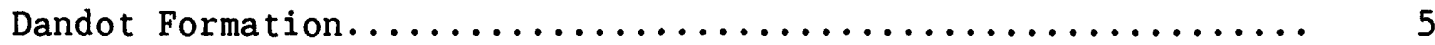

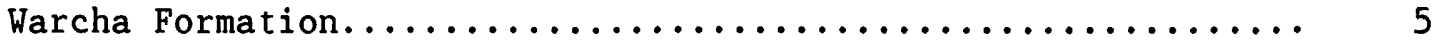

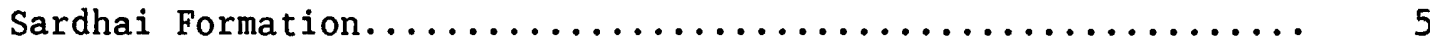

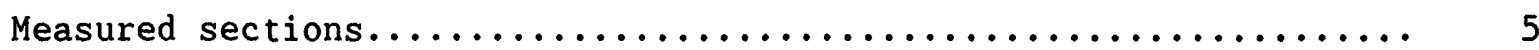

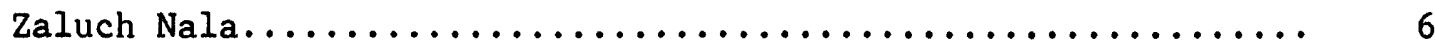

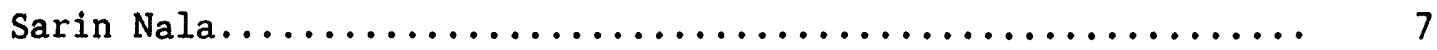

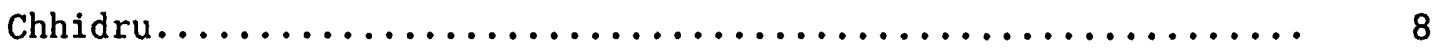

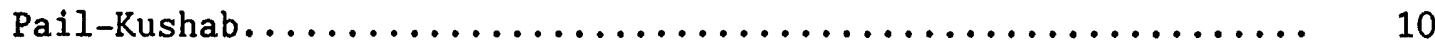

References cited................................. 11

\section{ILLUSTRATIONS}

Figure 1. Map showing location of Salt Range and measured sections discussed in text. Solid circle with adjacent number refers to measured section shown in figure $3 . \ldots \ldots \ldots$

2. Generalized stratigraphic column for sedimentary rocks exposed in the Salt Range....................

3. Preliminary stratigraphic correlations of Lower Permian rocks in the Salt Range. Number at top of each column refers to location of measured section shown in figure $1 \ldots \ldots \ldots \ldots \ldots \ldots \ldots \ldots \ldots \ldots$ 


\title{
MEASURED STRATIGRAPHIC SECTIONS OF THE LOVER PERMIAN NILAWAHAN GROUP, SALT RANGE, PUNJAB PROVINCE, PAKISTAN
}

\author{
B.E. Law and T. Hussnain
}

\section{INTRODUCTION}

As part of a cooperative geologic research project between the Geological Survey of Pakistan and the U. S. Geological Survey and funded by the U.S. Agency for International Development, several exposures of the Lower Permian Nilawahan Group in the Salt Range of north-central Pakistan (fig. 1) were measured and described during the months of February and March, 1989. Previous work on Lower Permian rocks has been, for the most part, reconnaissance in nature and only the Lower Permian Tobra Formation of the Nilawahan Group has been studied in any detail. Teichert (1967) has conducted the most significant work on the Tobra and has summarized the work of previous studies. He and workers before him recognized that depositional processes associated with glacial activity have played an important role in the depositional history of the Tobra Formation. The purpose of this report is to provide information regarding descriptions, thicknesses, and preliminary stratigraphic correlations of part of the Nilawahan Group.

\section{STRATIGRAPHY}

A generalized geologic column of stratigraphic units in the Salt Range is shown in figure 2. The Lower Permian Nilawahan Group is composed of four formations, which in ascending order are the Tobra Formation, Dandot Formation, Warcha Formation, and Sardhai Formation (Fatmi, 1973). The Nilawahan Group unconformably overlies Cambrian or Eocambrian rocks throughout the Salt Range and is conformably overlain by the Lower and Upper Permian Zaluch Group in the western and central parts of the Salt Range. In the eastern part of the Salt Range, the Nilawahan Group is unconformably overlain by Tertiary rocks, where it is eventually truncated, east of the town of Khewra (Gee, 1980).

\section{Tobra Formation}

The Tobra Formation is a very conspicuous dark-colored conglomeratic sandstone that has been studied by several workers, most notably by Teichert (1967). The conglomeratic clasts in the Tobra consist of granite, gneiss, quartzite, conglomerate, and metamorphic boulders and pebbles in a poorly sorted matrix composed of sandstone, siltstone, or silty mudstone. The clasts are as large as $45 \mathrm{~cm}$ in greatest dimension, well-rounded to sub-rounded, polished, and occasionally striated. Bedding characteristics vary from obscure to graded. The Tobra is thickest in the western part of the Salt Range where it is $154 \mathrm{~m}$ thick at the Zaluch Nala locality (fig. 1). In the central Salt Range it is discontinuous; in some areas it is present only as isolated boulders (fig. 3). In the eastern Salt Range, near Khewra, the Tobra thickens to over $10 \mathrm{~m}$. The tentative stratigraphic correlations of the Tobra Formation are shown in figure 3. 


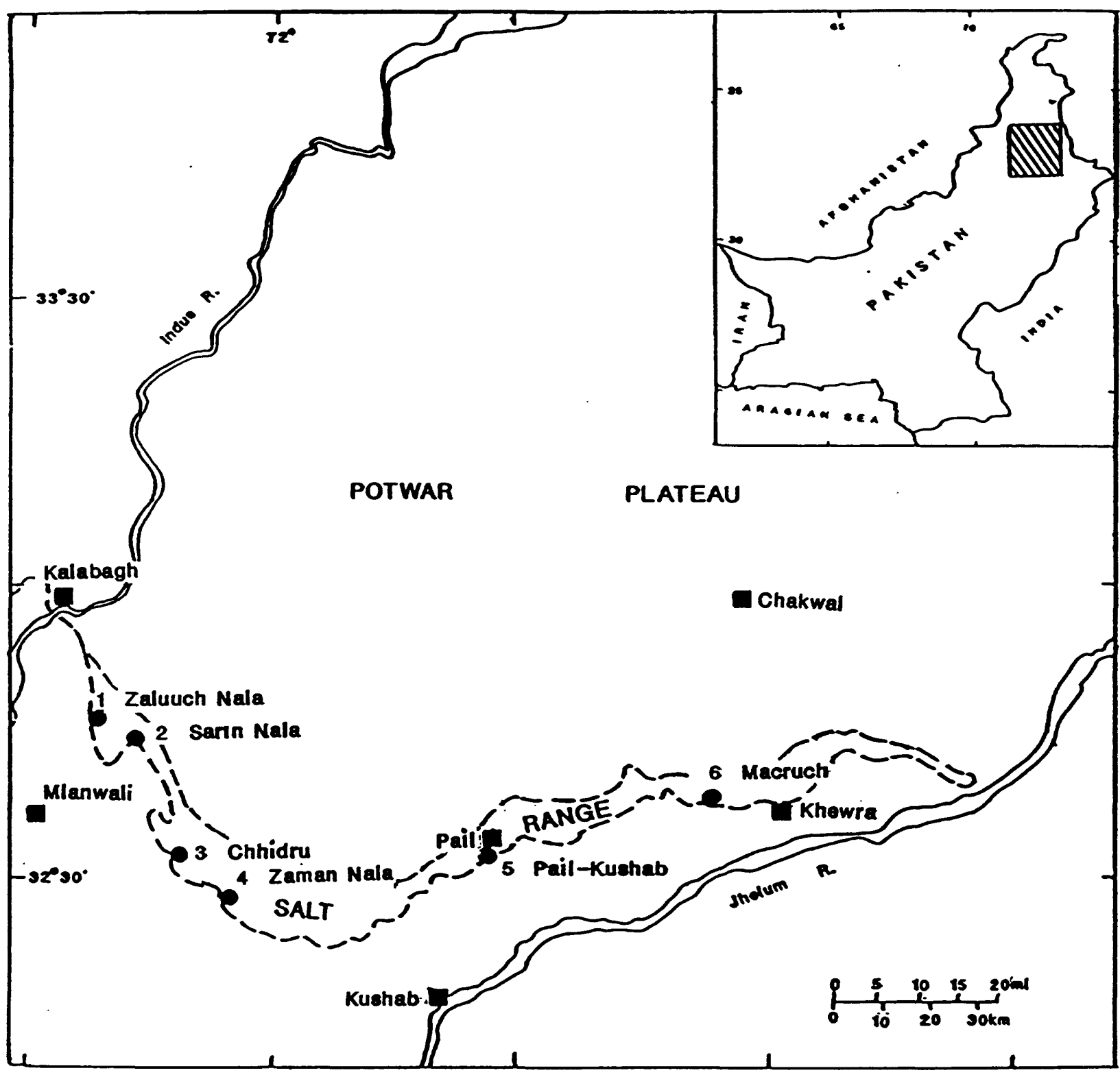

Figure 1.--Map showing location of Salt Range and measured sections discussed in text. Solid circle with adjacent number refers to measured section shown in figure 3 . 
GENERALIZEO GEOLOGIC COLUMN

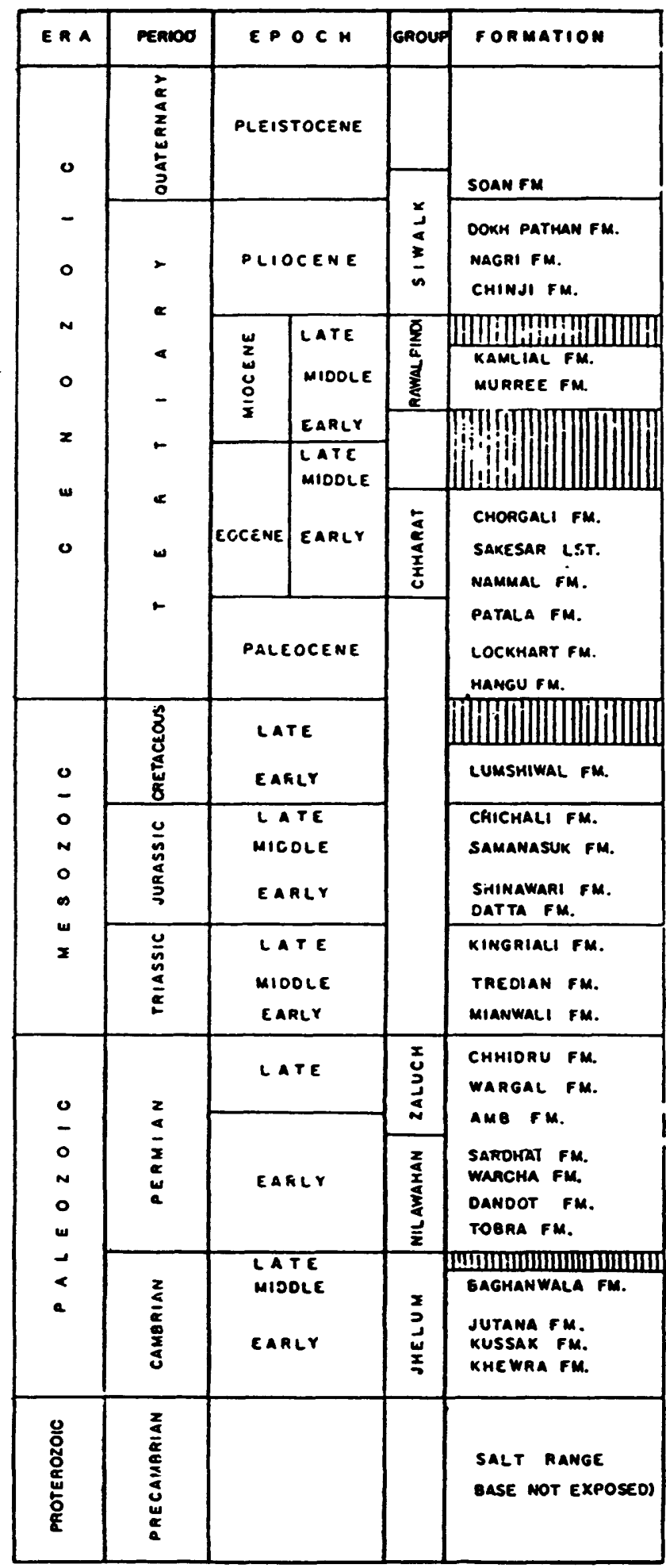

Figure 2.--Generalized stratigraphic column for sedimentary rocks exposed in the Salt Range. 

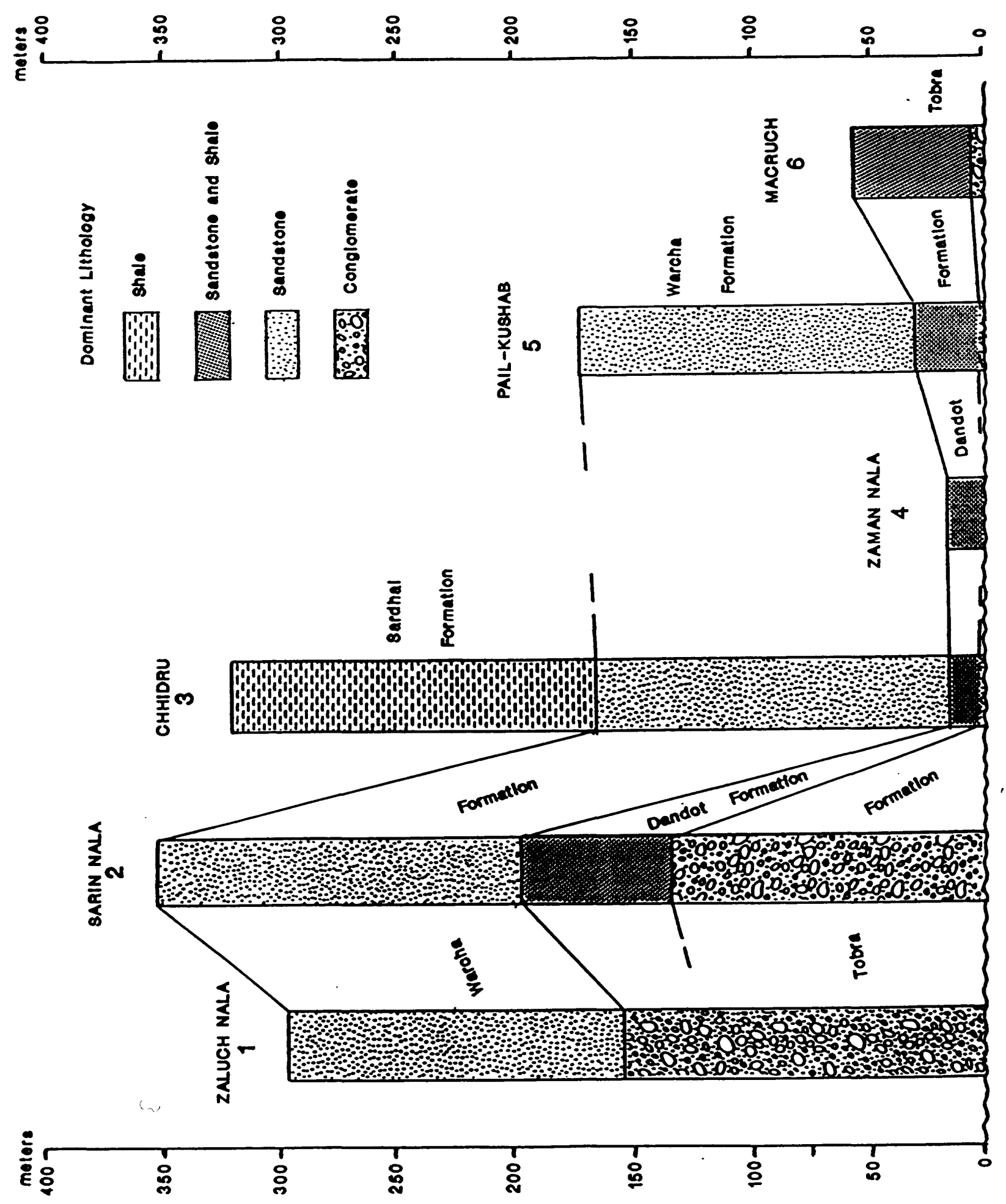

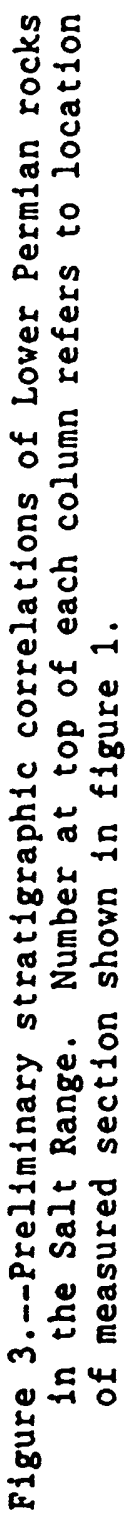




\section{Dandot Formation}

The Dandot Formation is not recognized throughout the Salt Range. It is best developed in the central part of the Salt Range, where it is a $\tan$ to olive-green sequence of interbedded sandstone, siltstone, and silty mudstone that is commonly burrowed, and the sequence has well developed flaser bedding. In the western part of the Salt Range, it is generally not recognizable, although, at the Sarin Nala locality (section 2, figs. 1 and 2), we measured $70 \mathrm{~m}$ of Dandot. The Dandot appears to be conformable with the underlying Tobra Formation but may actually be a facies equivalent to part of the Tobra. At the Sarin Nala locality (figs. 1, 3) and in outcrops near the Macruch locality (section 6, fig. 1), the Dandot contains boulders of granitic composition similar to those contained in the Tobra Formation. The tentative stratigraphic correlations of the Dandot are shown in figure 3.

\section{Warcha Formation}

The Warcha Formation is a reddish arkosic sandstone, siltstone, shale, and conglomeratic sequence that ranges in thickness from 140 to 155 $\mathrm{m}$. The Warcha overlies either the Dandot or Tobra Formations. The Warcha generally contains several fining-upward sequences with conglomeratic sandstones at the base and silty shales at the top. The lower parts of the fining-upward sequences are commonly trough cross-stratified, and the finer grained upper parts of the sequences are planar or ripple-laminated with occasional mudcracks. The large thickness variations of the underlying Dandot and Tobra Formations (fig. 3), and the abrupt, well-defined lower contact of the Warcha may indicate the presence of an unconformity. However, additional work is needed to resolve the nature of the contact. The tentative stratigraphic correlations of the Warcha Formation are shown in figure 3.

\section{Sardhai Formation}

The Lower Permian Sardhai Formation is a light- to medium-gray silty shale, siltstone, shale, and sandstone unit that commonly forms poorly exposed slopes. The one section of the Sardhai Formation that we measured at the Chhidru locality (section 3, figs. 1, 3) is $166 \mathrm{~m}$ thick. The base of the Sardhai is lithologically gradational with the underlying Warcha Formation and grades upward into the overlying Lower Permian Amb Formation of the Zaluch Group.

\section{MEASURED SECTIONS}

The location of Lower Permian outcrops visited during the course of field investigations are shown on figure 1 , and the tentative stratigraphic correlations are shown on figure 3. Although several outcrops were visited, only four sections were measured and described in detail. Sections were measured with a tape and Brunton compass. At locations where the rocks are steeply dipping, those portions of the sections measured with a Brunton compass were corrected graphically. 


\section{Zaluch Nala}

Measured by Ben E. Law and Tamanna Hussnain, February, 1989. Section begins about $350 \mathrm{~m}$ from entrance to Zaluch Nala near top of Eocambrian Salt Range Formation ( $32^{\circ} 46^{\prime} 59^{\prime \prime} \mathrm{N}$. lat, $710^{\circ} 38^{\prime} 2^{\prime \prime} \mathrm{E}$. long, section no. 1 on figure 1) and continues east and north for about $800 \mathrm{~m}$.

\section{Warcha Formation:}

(meters)

Conglomeratic sandstone, sandstone, siltstone, and silty shale, white to light-gray, reddish-white. Sandstone is very fine- to coarse-grained, non-calcareous. Granules and pebbles composed of angular to sub-angular feldspar, quartz, and lesser amounts of mafic rocks and minerals. Unit consists of several fining-upward sequences as thick as $30 \mathrm{~m}$, with coarse-grained conglomeratic sandstones at the base grading up to very fine grained sandstone and silty shale. Conglomeratic sandstones and sandstones are commonly trough cross-stratified and silty shales are ripple laminated. Tops of fining-upward sequences are erosional and abruptly overlain by conglomeratic sandstones of the next fining-upward sequence.

Total Warcha Formation--cos

\section{Tobra Formation:}

Conglomeratic sandstone, gray, lavender, black, very poorly sorted; conglomeratic clasts are composed of granite, quartzite, and dark-colored metamorphic rocks that range in size from 1 to $25 \mathrm{~cm}$ and are well-rounded to sub-angular; a few of the clasts are striated. The clasts are suspended in a matrix composed of sandstone, siltstone, and mudstone. There is no apparent fabric or orientation of the clasts-_- 101.0

Conglomeratic sandstone, brown to tan, non-calcareous. Sandstone contains abundant grains of red-colored feldspars, poorly sorted, very fine to coarse grained, angular to rounded. Conglomeratic clasts are composed of granite, quartzite, and metamorphic rocks. Graded bedding occurs in sandstone lenses containing small pebbles and granules-- 11.2

Conglomeratic sandstone, gray, lavender, black, very poorly sorted. Conglomeratic clasts are composed of granite, quartzite, and dark-colored metamorphic rocks that range in size from 1 to $25 \mathrm{~cm}$ and are well-rounded to subangular. The clasts are suspended in a matrix composed of sandstone, siltstone, and mudstone. There is no apparent fabric or preferred orientation of the clasts. Base not exposed---- 42.2

Total Tobra Formation-_ 154.4 


\section{Sarin Nala}

Measured by B. E. Law and T. Hussnain, March, 1989. Section begins about $900 \mathrm{~m}$ from entrance to Sarin Nala, at base of Eocambrian Salt Range Formation $\left(32^{\circ} 44^{\prime} 51^{\prime \prime}\right.$ N. lat, $71^{\circ} 43^{\prime}$ 04" E. long, section no. 2, fig. 1) and continues north about $150 \mathrm{~m}$.

Warcha Formation: (Top not exposed; faulted)

Sandy, silty shale, red to lavender; irregular wavy

Thickness

(meters) bedding; weathers to form slopes

57.6

Sandstone, pale red, medium-to coarse-grained; arkosic with angular feldspar grains; fines upward; trough cross-stratified-

Silty shale, red to lavender, irregular wavy bedding; poorly exposed-

Sandstone, red, fine-to coarse-grained; arkosic with angular feldspar grains, trough cross-stratified

Silty shale and siltstone, red to lavender, irregular wavy bedding; contains a few thin sandstone beds

Sandstone, red, medium-to coarse-grained with a few granule size grains; arkosic with angular feldspar grains; fines upward; trough cross-stratified-_...-..-_-_--

Total Warcha Formation

\section{Dandot Formation:}

Conglomeratic sandstone, tan to light gray, fine- to medium-grained; few thin $(<1.0 \mathrm{~cm})$ discontinuous, carbonaceous shale lenses. Coal is locally mined from this interval-a

Sandstone, tan to light-gray, fine- to medium-grained;

bedding indistinct-are

bedding; matrix-supported clasts---
Conglomerate, tan; fines upward; forms resistant ledge; erosional base stone with few lenses of pebble conglomerate, tan to light-brown; fines upward; erosional base-..............

4.6

9.4

8.0

Conglomeratic sandstone, tan; bedding indistinct. Boulders well-rounded and as much as $35 \mathrm{~cm}$ in longest dimension. Unit fines upward; forms resistant ledge--.---

Shale, lavender to light-green, splintery; top of unit is erosional; weathers to slope--.--

Sandstone and silty shale, dark-brown to lavender; indistinct bedding

Tobra Pormation:

Conglomeratic sandstone, lavender to dark-brown; sandstone fine- to coarse-grained, poorly sorted, angular grains; clasts composed of granite, gneiss, conglomerate, and mafic rocks that are well-rounded and 12 much as $45 \mathrm{~cm}$ in longest dimension- 
Tobra Formation:

Sandstone, tan to light-brown; plant fragments; contains a few thin conglomeratic lenses-_._. 6.4

Conglomeratic sandstone, lavender to dark-brown; sandstone is fine- to coarse-grained, poorly sorted; bedding indistinct; granitic clasts; forms resistant ledge-

Conglomeratic sandstone, tan to medium-gray; base of unit is erosional. Unit contains three finingupward sequences

Conglomeratic sandstone, lavender to dark-brown; sandstones are fine- to coarse-grained, poorly sorted with angular grains; bedding indistinct; clasts are

matrix supported--
Conglomeratic sandstone, tan; grades up to siltstone; planar cross-stratified and ripple-laminated at top. Transport direction $\mathrm{N} 40^{\circ} \mathrm{E}$

Conglomeratic sandstone and siltstone, lavender to dark-brown; sandstone fine- to coarse-grained, poor sorting; angular grains; bedding indistinct. Clasts composed of granite, gneiss, conglomerate, and mafic rocks; clasts are rounded to sub-rounded and as much as $45 \mathrm{~cm}$ in longest dimension. Base not exposed--..--

\section{Chhidru}

Measured by B. E. Law and T. Hussnain, February, 1989. Section begins at top of Cambrian rocks, about $350 \mathrm{~m}$ from entrance to unnamed canyon approximately 1.7 kilometers east of Chhidru village ( $32^{\circ} 32^{\prime} 41^{\prime \prime}$ N. lat, $71^{\circ} 47^{\prime} 48^{\prime \prime} \mathrm{E}$. long, section no. - on figure 3 ) and continues northeast about $600 \mathrm{~m}$ to base of Permian Amb Formation.

Thickness (meters)

\section{Sardhai Formation:}

Silty shale, gray; grades up to interbedded, very fine-grained sandstone and carbonaceous shale; ripple

Carbonaceous shale, brown to dark-gray, thinly laminated; contains jarosite-_ 1.0

Silty shale, mottled, gray, green, lavender, calcareous.

Contains irregularly-shaped calcareous nodules; forms slope-_._- 111.8

Sandstone, tan to brown, fine- to coarse-grained; iron concretions; trough cross-stratified-_._- $\quad 3.0$

Silty shale, gray; bedding indistinct____._. 17.6

Total Sardhai Formation-_ 155.8 
Warcha Formation:

Conglomeratic sandstone, sandstone, siltstone, and silty shale, red to lavender; sandstones are arkosic with abundant angular feldspar grains; bedding is horizontal parallel laminated, trough cross-stratified, and ripple laminated. Occasional mudcracks at top of silty shales-- reddish-white, fine- to coarse-grained, arkosic

Sandstone, reddish-white, fine- to coarse-grained, arkosic;
with angular feldspar grains, poor sorting. Granule to pebble-size clasts composed of silty shale, siltstone, and

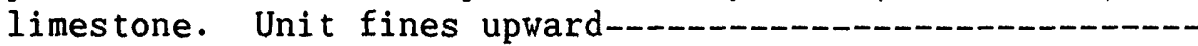
114.8

Silty shale, mottled, lavender to gray; bedding indistinct; forms slope-

Sandstone, interbedded with thin silty shale, reddishwhite, weathers red; fine- to coarse-grained, arkosic, slightly calcareous; bedding is horizontal parallel laminated and cross-stratified_.....................

\section{Dandot Formation:}

Silty shale, olive-green, thin-bedded; forms slope-

Sandstone, $\tan$ to olive green, fine- to medium- grained, ripple laminated with interbedded, thin, irregularly bedded silty shale and mudstone; burrowed-

Sandstone and shale, tan to olive-green; flaser bedding; resistant ledge

Sandstone, tan; very fine- to fine-grained, friable; horizontal and ripple laminated; trough crossstratified; forms resistant ledge-

Sandstone, siltstone, carbonaceous shale, tan, geenish-gray; sandstone very fine-grained; fair sorting; flaser structure and ripple laminated; forms slope

Sandstone, greenish-tan; very fine- to fine-grained; bedding indistinct, ripple laminated at top; resistant ledge- siltstone, and coaly mudstone, tan to

Sandstone, siltstone, and coaly mudstone, tan to
greenish-gray; sandstone is very fine grained, thin-bedded, and irregular, ripple laminated, burrowed; forms slope-

\section{Tobra Formation:}

Represented by the occurrence of an occasional granitic boulder; otherwise, not present. Angular discordance between Permian rocks and underlying Cambrian rocks-_...-- 


\section{Pail-Kushab}

Measured by B. E. Law and T. Hussnain, March, 1989. Section located on west side of Pail to Kushab road. Section begins at top of Cambrian Kussak Formation, about 3.5 kilometers north of the foot of the Salt Range $\left(32^{\circ} 33^{\prime} 28^{\prime \prime} \mathrm{N}\right.$. lat, $72^{\circ} 27^{\prime} 14^{\prime \prime} \mathrm{E}$. long, section no. 5, figure 1) and continues north for about 325 meters.

\section{Warcha Formation:}

Alternating sequence of arkosic, poorly sorted sandstones

Thickness and shaly siltstones, pink to light-red; weathers red to lavender; sandstones fine- to coarse-grained with lenses of conglomeratic sandstone; clasts are pebble size and are angular to sub-angular; trough cross-stratified; calcareous nodules occur in upper $35 \mathrm{~m}$

Dandot Formation:

Sandy siltstone, olive-green; thinly laminated; micaceous-----

Silty sandstone, tan to light-gray, thin-bedded, platy, ripple laminated, burrowed. Upper $1.0 \mathrm{~m}$ resistant sandstone; ripple laminated-

Sandy siltstone and shale, olive-green, micaceous; poorly exposed

Sandstone, olive-green to tan, very fine- to fine-grained, micaceous, burrowed; ripple and

parallel laminated-and siltstone and sandstone, tan, thin-bedded,
Shaly sing platy; ripple-laminated; burrowed-

Silty sandstone, olive green to medium-gray, burrowed; flaser bedding; grades up to siltstone, ripple-laminated-

Sandstone, olive-green to tan, very fine- to fine-grained; non-calcareous; horizontal parallel

laminated and ripple laminated-

Sandstone and silty shale, tan to brown, burrowed; flaser bedding

Sandstone, tan to brown; very fine- to medium-grained; some small $(<.2 \mathrm{~cm})$ pebbles; minor amount of burrowing; wood fragments; horizontal and trough cross-stratified; coarsens upward; transport direction, $\mathrm{N} 3^{\circ} \mathrm{E}-$ sandy mudstone, greenish-tan, highly burrowed, ripple laminated; flaser bedding; mottled appearance; ripple crests trend $\mathrm{S} 62^{\circ} \mathrm{W}$

\section{Tobra Formation:}

Conglomerate; pebbles and small boulders; granitic clasts. Base is erosional; striations on top of Cambrian rocks trending in $\mathrm{N} 55^{\circ} \mathrm{W}$ direction- 


\section{REFERENCES CITED}

Fatmi, A. N., 1973, Lithostratigraphic units of the Kohat-Potwar Province, Indus Basin, Pakistan: Geological Survey of Pakistan Memoir 10, $80 \mathrm{p}$.

Gee, E. R., 1980, Map of the Salt Range: United Kingdom Directorate of Surveys for the Government of Pakistan, 6 sheets, 1:50,000 scale.

Teichert, C.,1967, Nature of Permian glacial record, Salt Range and Khisor Range, West Pakistan: Neues Jahrbuch für Geologie und Paläontologie. Abhandlungen, v. 129, p. 167-184. 